\title{
PENGEMBANGAN APLIKASI SISTEM INFORMASI INVENTORY PADA CV WIJAYA LAS KEDIRI MENGGUNAKAN MODEL WATERFALL
}

\author{
Rizal Arianto', Abdul Kholiq Al Anam², Berliana Devi ${ }^{3}$, Andy Rachman ${ }^{4}$ \\ Jurusan Teknik Informatika, Fakultas Teknik Elektro dan Teknologi Informasi, \\ Institut Teknologi Adhi Tama Surabaya
}

\section{Article Info}

Article history:

Received Jun $12^{\text {th }}, 2021$

Revised Aug 20 2021

Accepted Aug $31^{\text {th }}, 2021$

\section{Keyword: \\ Inventori \\ Persediaan \\ Website \\ Metode Waterfall \\ Aplikasi}

\begin{abstract}
Sistem inventory merupakan sistem persediaan barang yang menjadi aspek penting bagi perusahaan dalam perusahaan barang-barang tersebut disimpan untuk memenuhi kebutuhan perusahaan Inventori merupakan barang yang disimpan atau digunakan untuk dijual kembali, yang dapat berbentuk bahan baku yang disimpan dan dijual.Dari hasil penelitian yang dilakukan rizal arianto pada CV Wijaya Las Kediri pengecekan persediaan material barang bersifat manual dari masalah tersebut maka dibutuhkan sistem informasi inventor. Untuk Mengembangkan Sistem Informasi Inventori kami menggunakan metode Waterfall. Hasil pengujian didapatkan bahwa metode Waterfall dapat digunakan untuk membuat Sistem Informasi Inventori sehingga membantu pemilik maupun staff perusahaan dalam meningkatkan pelayanan dan penjualan, mempermudah pekerjaan staff dalam mencatat data keluar masuk barang, dan pembuatan laporan. Pada penelitian ini kami melakukan uji kelayakan aplikasi dengan melakukan uji pada staff perusahaan CV Wijaya Las Untuk mengetahui layak atau tidaknya kami menggunakan ISO 9126-3 dan hasil dari penilaian diperoleh kemudahan dipahami sebesar 83\%, Kemudahan dipelajari sebesar 80\% Responsif pada program sebesar $75 \%$ Kemudahan akses pada program sebesar $80 \%$ dan kesesuaian tujuan sebesar $86 \%$
\end{abstract}

Copyright () 2021 STMIK Triguna Dharma. All rights reserved.

\section{Corresponding Author:}

Nama : Andy Rachman, S.T., M.Kom,

Program Studi : Teknik Informatika

Institut Teknologi Adhi Tama Surabaya

Email: rizalarianto16041998@gmail.com

\section{PENDAHULUAN}

Persediaan didefinisikan sebagai barang jadi yang disimpan atau digunakan untuk dijual pada periode mendatang, yang dapat berbentuk bahan baku yang disimpan untuk diproses, barang dalam proses manufaktur dan barang jadi yang disimpan untuk dijual maupun diproses inventori yang berarti persediaan [1]. Dalam pengembangan perangkat lunak, khususnya dalam pengembangan perangkat lunak telah ditetapkan menggunakan model pengembangan perangkat lunak. Pengembangan perangkat lunak dengan adanya model pengembangan perangkat lunak pengembang tidak salah dari tujuan perangkat lunak yang dikembangkan.

Model waterfall merupakan salah satu model tertua dalam pengembangan perangkat lunak. Sistem inventory adalah bagian yang disediakan dalam proses yang terdapat dalam suatu perusahaan untuk di produksi, serta barang jadi yang disediakan untuk memenuhi permintaan dari konsumen setiap waktu yang disimpan dan dirawat menurut aturan tertentu dalam keadaan siap pakai dan tersimpan dalam database [2]. 
Dalam melakukan perancangan system penulis menggunakan UML (Unified Modeling Language) Yang meliputi Usecase diagram untuk menggambarkan interksi antar actor dengan system, UML merupakan metode yang digunakan untuk menggambarkan dan mendokumentasikan desain perangkat lunak system [3]. Sistem Informasi merupakan suatu asosiasi terdiri dari beberapa modul yang saling terintegrasi dimana menyajikan informasi dan pengolahan data untuk disajikan sesuai dengan kebutuhan user, database, source code dan model design mewakili dari untaian suatu rancangan sistem informasi berguna untuk mempermudah dalam pengembangan dan maintenance [4].

Pada penelitian sebelumnya yang dilakukan oleh Andy Rachman. Model waterfall dipercaya oleh pengembang aplikasi sebagai model yang dapat membantu pengembang dalam melakukan pembuatan aplikasi. Salah satu keunggulannya adalah fase dan alur model waterfall sangat jelas dan mudah dipahami [5]. Maka dari itu dibuatlah sistem informasi inventory pada perusahaan CV Wijaya Las yang berguna untuk membantu perusahaan dalam meningkatkan pelayanan dan penjualan, mempermudah pekerjaan staff dalam mencatat data keluar masuk barang, dan pembuatan laporan barang masuk dan keluar barang dengan adanya inventori ini data tersimpan dengan aman dan mudah dikelola oleh staff maupun kepala perusahaan dan menghemat waktu dalam proses pencatatan stok barang.

Pada penelitian sebelumnya Model SDLC adalah Siklus hidup pengembangan perangkat lunak (SDLC) sangat penting dan tetap menjadi bagian terpenting dari pengembangan perangkat lunak dalam rekayasa kebutuhan. Ada beberapa model SDLC masing-masing antara diantaranya adalah model waterfall [6]. Untuk model pengembangan pada program inventori ini kami menggunakan model SDLC Waterfall dengan menggunakan model ini diharapkan dapat mempermudah pembuatan laporan barang masuk dan keluar dan menghasil kan laporan yang jauh lebih baik. Pengembangan SDLC pada inventori sebelumnya pernah dilakukan oleh Frieyadie Setiyorini dan Tyas pada jurnal implementation of inventory information system design using economic order quantity method [7].

\section{METODE PENELITIAN}

\subsection{Metode Observasi}

Metode observasi dilaksanakan oleh penulis dengan cara mengamati, memahami secara langsung dengan cara meneliti proses pengolahan data. Untuk mendapatkan data yang valid dan informasi yang benar yang dibutuhkan untuk dikembangkan dalam proses pembuatan aplikasi system informasi inventori pada CV Wijaya Las

a. Metode Interview

Metode interview dilaksanakan dengan cara melakukan tanya jawab dengan pemilik perusahaan dan admin maupun staff pada CV Wijaya Las, wawancara secara langsung

b. Studi Literatur

Studi literatur dilaksanakan dengan mempelajari melalui literature baik dari buku maupun jurnal dan situs - situs yang ada di internet serta berkonsulatasi ke dosen pembimbing kerja praktek.Dari penjelasan metodologi secara umum di atas akan dijelaskan lebih rinci sebagai berikut Penentuan lokasi kerja praktek di perusahaan CV Wijaya Las,

c. Implementasi

Berdasarkan pada permasalahan yang diberikan oleh kepala perusahaan Wijaya Las, maka peneliti Melakukan perancangan dan pembuatan website menggunakan Bahasa pemrograman PHP dengan menggunakan framework Laravel dan database MySQL. Dan melakukan penulis melakukan pengujian menggunakan black box testing dan melakukan pengujian aplikasi system informasi inventori menggunakan ISO 9126-3 untuk menguji kelayakan melalui pihak perusahaan mengambil kesimpulan dan melakukan Penulisan hasil laporan kerja praktek

\subsection{Perangkat Lunak yang dibutuhkan}

Untuk mendukung dalam pembuatan inventori pada CV Wijaya Las Kediri maka penulis menggunakan berbagai tools sebagai berikut :

1. Pengertian Web atau website adalah kumpulan dari halaman situs dan dokumen yang tersebar di beberapa computer server yang berada di seluruh penjuru dunia dan terhubung menjadi satu jaringan melalui jaringan yang disebut internet [8]. 
2. XAMPP adalah perangkat lunak bebas,yang mendukung banyak sistem operasi,merupakan kompilasi dari beberapa program.Fungsinya adalah sebagai server yang berdiri sendiri (localhost), yang terdiri atas program Apache HTTP Server, MySQL database, dan penerjemah bahasa yang ditulis dengan bahasa pemrograman PHP dan Perl. Nama XAMPP merupakan singkatan dari X (empat sistem operasi apapun), Apache, MySQL, PHP dan Perl. Program ini tersedia dalam GNU General Public License dan bebas [9].

3. PHP adalah salah satu server side yang dirancang khusus untuk aplikasi web PHP disisipkan diantara bahasa HTML dan karenabahasa server side, maka bahasa PHP akan dieksekusi di server PHP merupakan singkatan dari "PHP: Hypertext Preprocessor", adalah sebuah bahasa scripting yang terpasang pada HTML[10].

4. Laravel adalah Framework dirancang untuk meningkatkan kualitas perangkat lunak, menyederhanakan otentikasi, memudahkan perutean, memudahkan akses, dan meningkatkan daya dalam kerangka situs web. Laravel adalah aplikasi kerangka kerja dengan sintaks yang elegan dan memiliki luas fungsi seperti keamanan, penyimpanan kata sandi, pengingat dan pengaturan ulang kata sandi, enkripsi, dan validasi [11].

5. Visual Studio Code (VS Code) ini adalah sebuah teks editor ringan dan handal yang dibuat oleh Microsoft untuk sistem operasi multiplatform, artinya tersedia juga untuk versi Linux, Mac, dan Windows. Teks editor ini secara langsung mendukung berbagai bahasa pemrograman serta bahasa pemrograman lainnya dengan bantuan plugin yang dapat dipasang Teks editor VS Code juga bersifat open source [12].

6. PowerDesigner Powerdesigner ialah software pemodelan yang diproduksi oleh Sybase, saat ini menjadi miliki SAP. Ini dapat berjalan baik di bawah Microsoft Windows software Ini memberikan dukungan akan desain perangkat lunak arsitektur berbasis model, dan menyimpan model menggunakan berbagai ekstensi file, seperti BPM, .CDM, dan .PDM [13].

7. Draw io adalah website dan software yang digunakan untuk membuat flowchat, draw io berguna untuk merancang Use Case diagram maupun activity diagram [14].

\section{ANALISA DAN HASIL}

\subsection{Usecase Diagram}

Usecase Diagram adalah diagram yang menggambarkan hubungan antara aktor dengan system. Adapun usecase diagram pada system dapat dilihat pada gambar 1 .

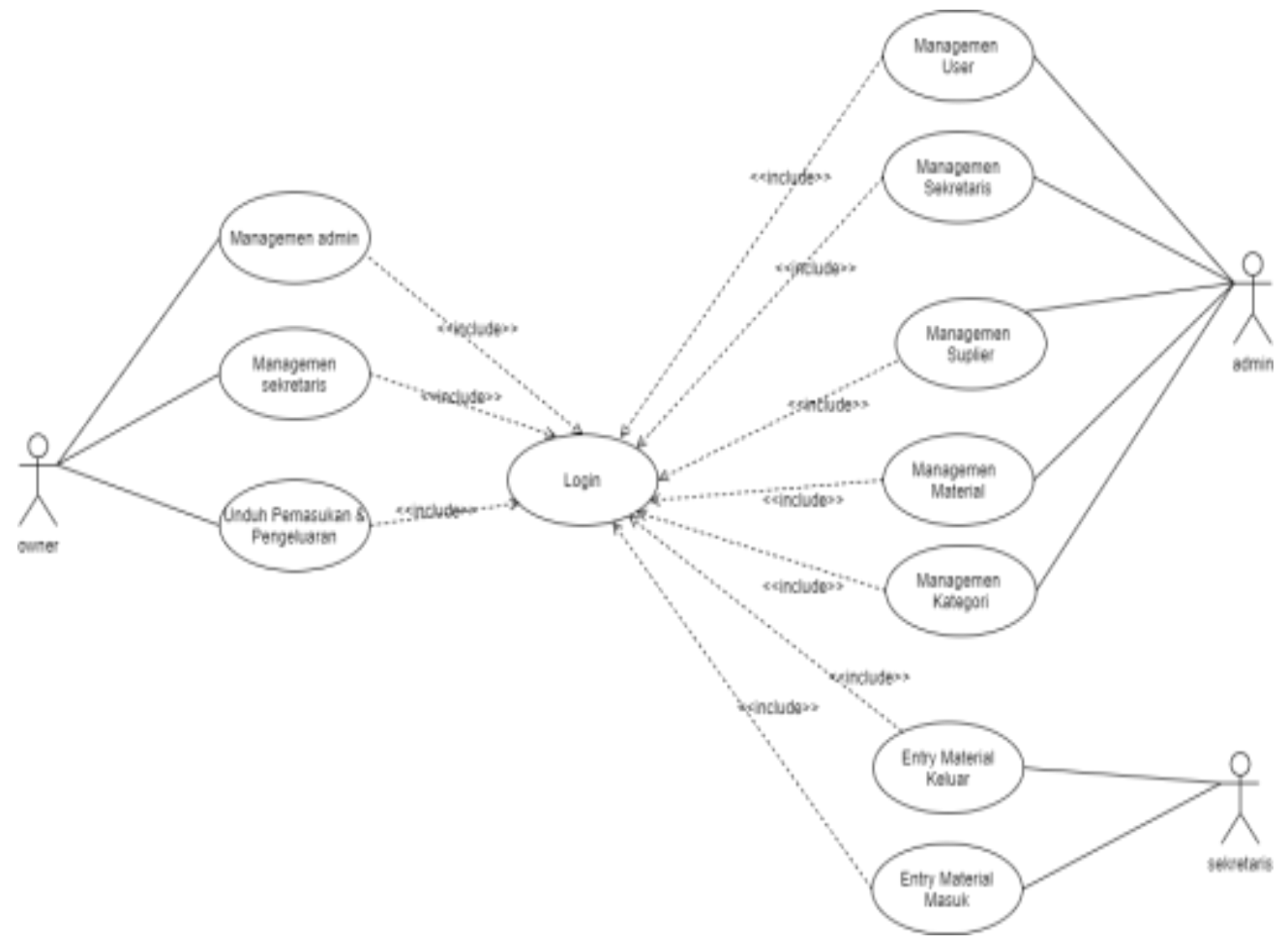

\subsection{Activity Diagram}

Gambar 1. Diagram Usecase Inventori

Activity Diagram Sistem inventory pada CV Wijaya Las dibuat untuk menggambarkan aktifitas apa saja yang bias dilakukan oleh user seperti aktifitas apa saja yang bisa dilakukan sekretaris yang dapat 
memanajeman material masuk dan material keluar dari sisi proses system yang tengah dirancang [3] berbeda dengan aktifitas yang dilakukan sekretaris, admin memiliki aktifitas seperti menambahkan maupun menghapus data supplier dan data material.[15] dan owner memiliki aktifitas seperti memanajemen admin,sekretaris dan mencetak laporan masuk dan keluar

Pada sistem penilaian level user dibagi menjadi 3 yaitu admin, sekretaris, dan owner. Tugas dari masingmasing user tersebut akan dijelaskan pada bagian berikut :

\subsection{Activity Diagram Admin}

Admin adalah orang yang menjadi operator untuk mengelolah program Inventory seperti penambahan data berupa data user, suplier, update data sekertaris dan data kategori. Activity diagram dari admin sebagai berikut:

a. Login pada admin

Adapun activity diagram admin management user dapat dilihat pada gambar 2

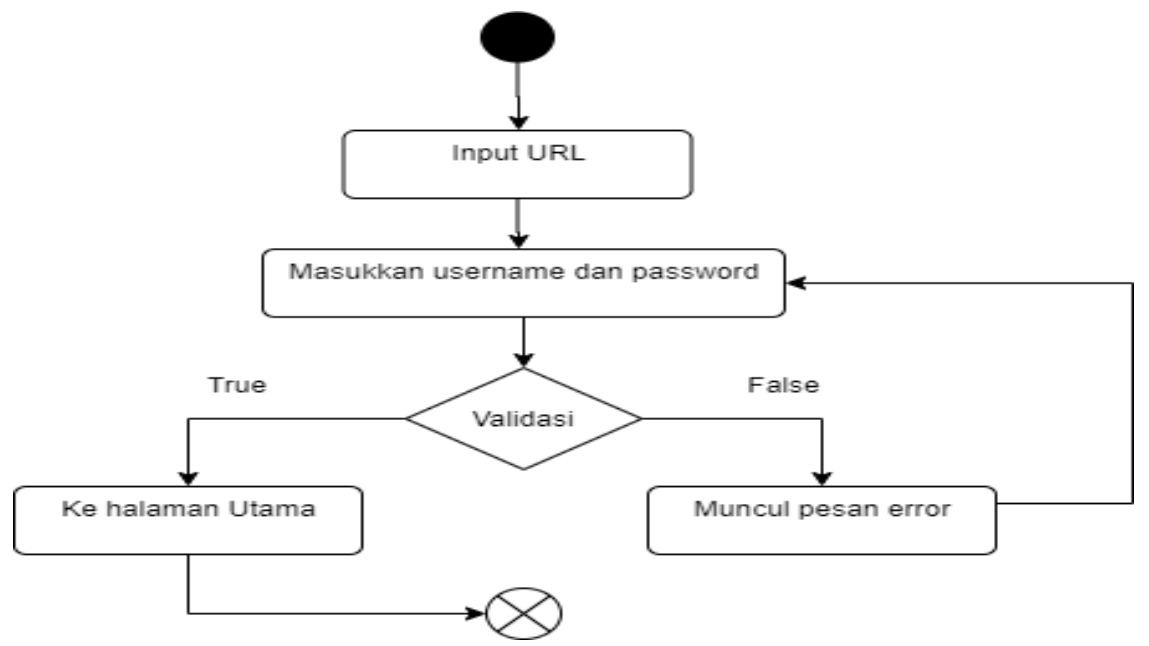

Gambar 2. Login pada admin

b. Admin management user

Adapun activity diagram admin management user dapat dilihat pada gambar 3

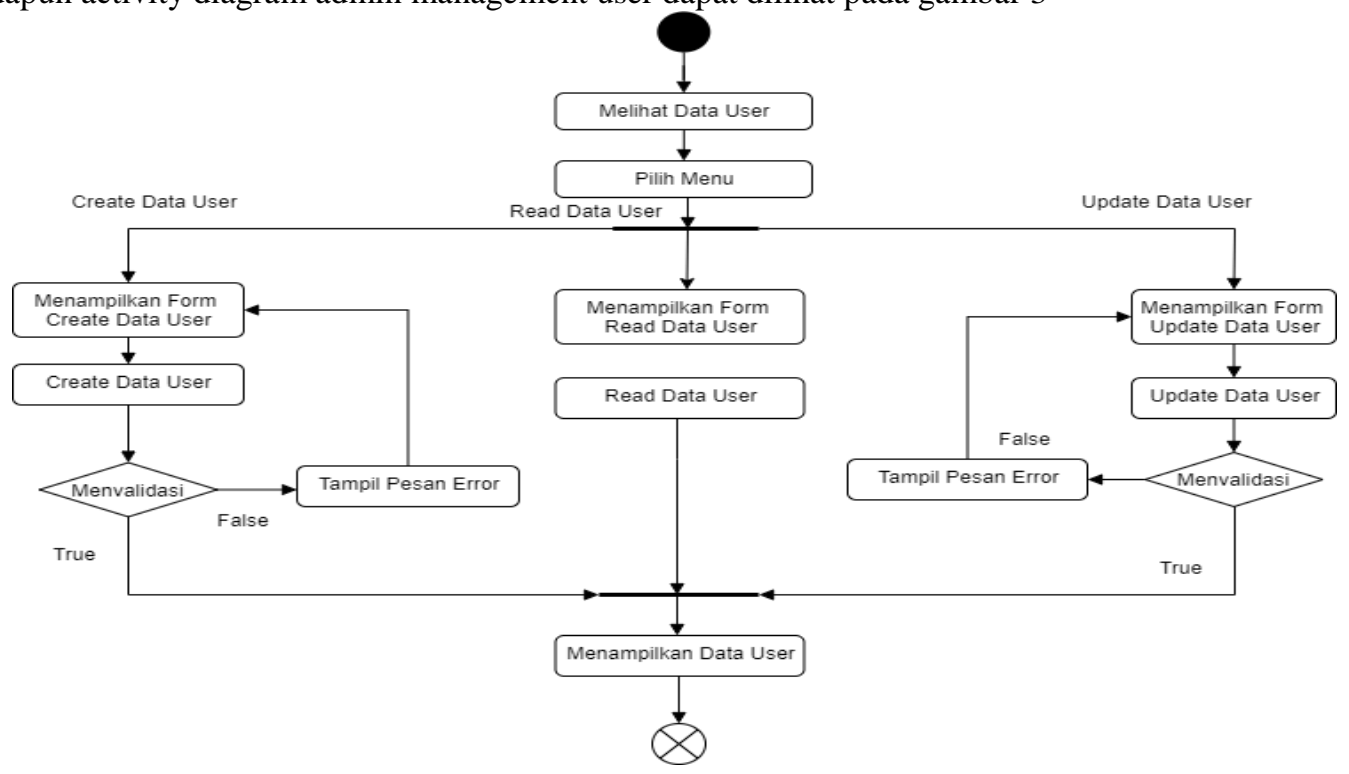

Gambar 3. Admin Management user 
c. Admin management supplier

Adapun activity diagram admin management suplier dapat dilihat pada gambar 4 .

d. Management sekretaris

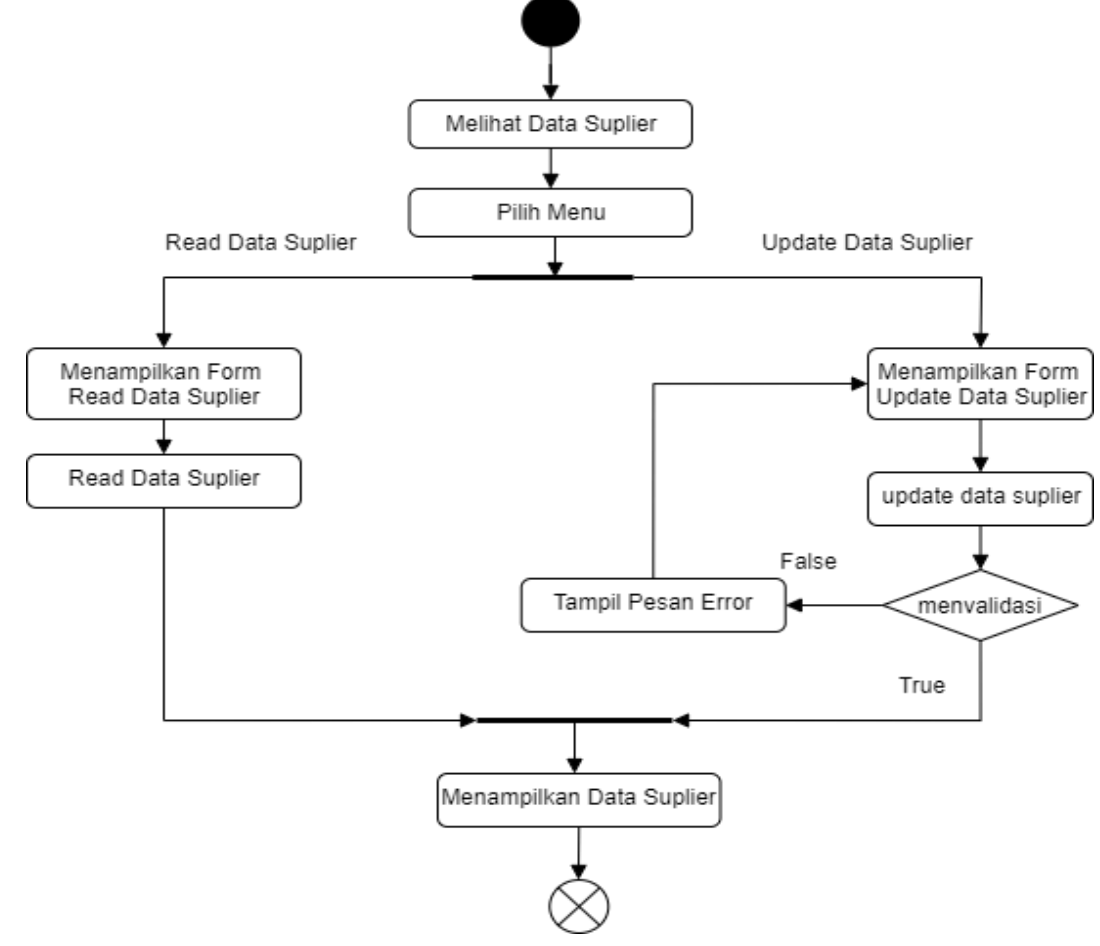

Gambar 4. Admin management supplier

Adapun activity diagram Management sekretaris dapat dilihat pada gambar 5

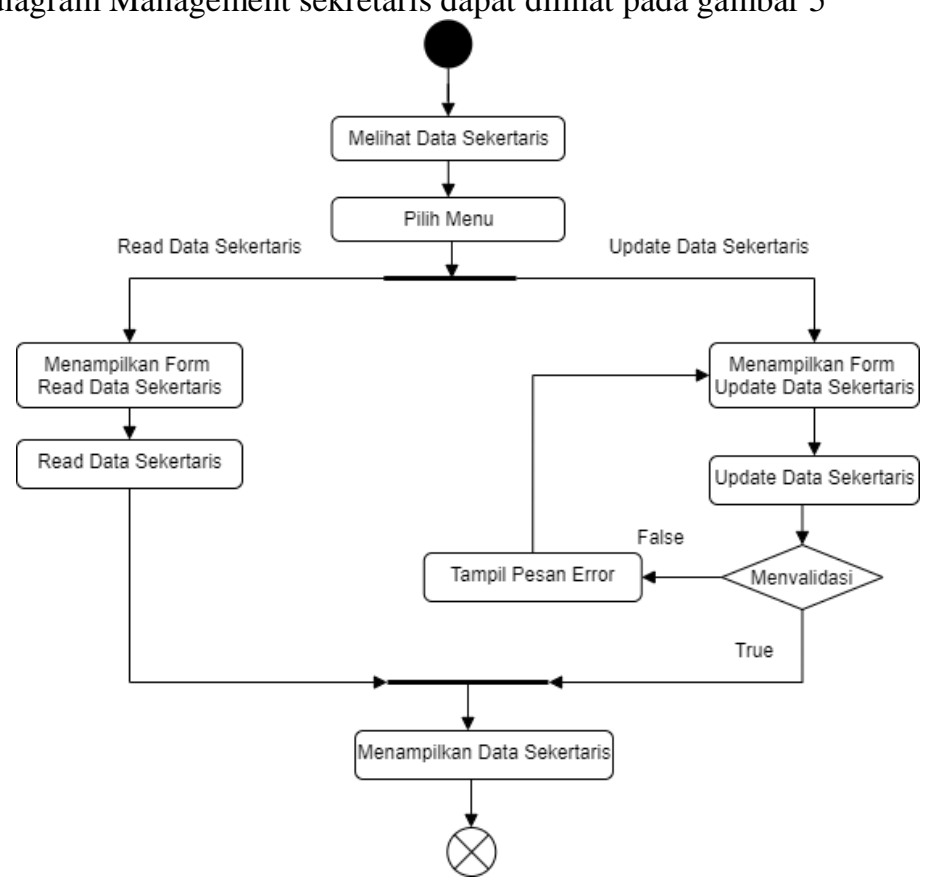

e. Management owner

Gambar 5. Management Sekretaris

Adapun activity diagram Management owner dapat dilihat pada gambar 6 


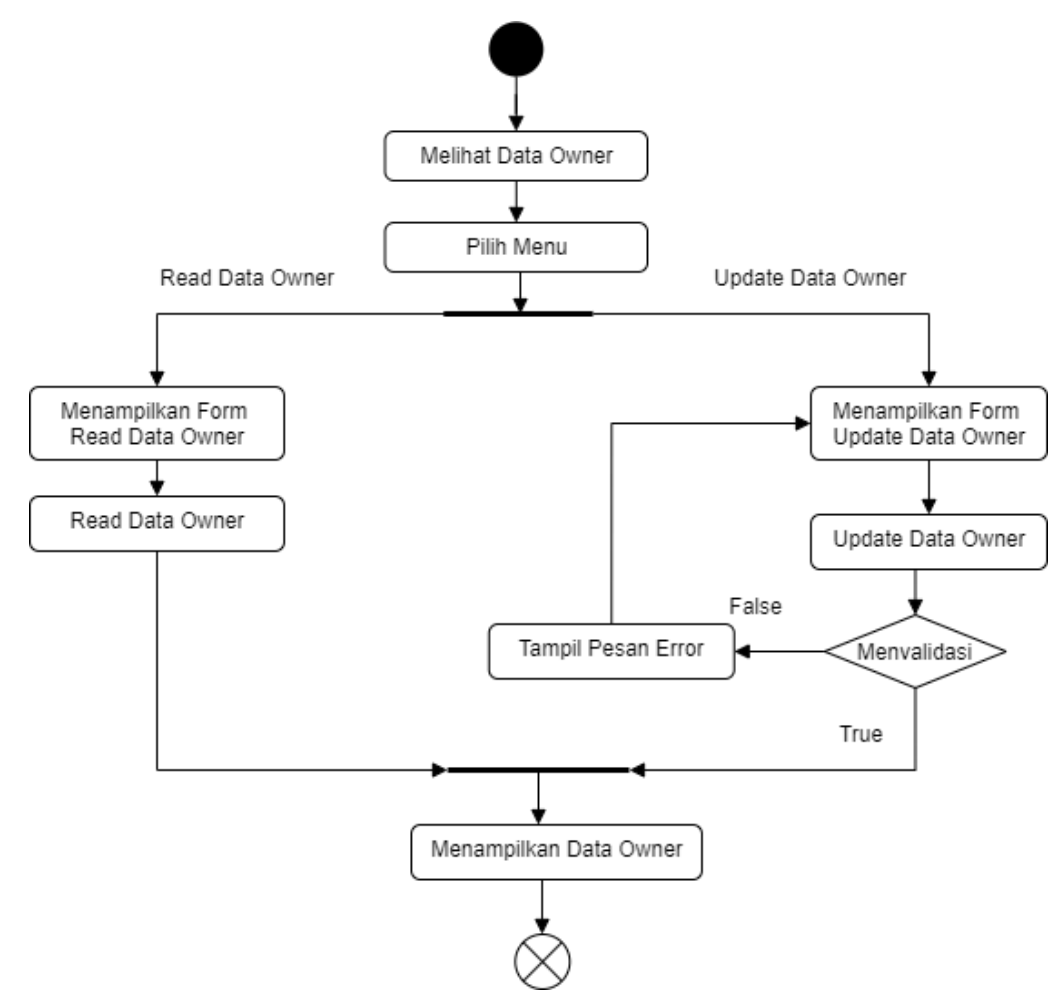

Gambar 6. Management owner

f. Activity Diagram Transaksi

Activity diagram pada diagram transaksi berguna untuk menggambarkan alur proses transaksi pada system inventori disini sekretaris dapat melihat data transaksi dan memilih menu disini sekretaris memiliki pilihan untuk mengakses melihat transaksi material keluar dan material masuk, setelah memilih sekretaris dapat melihat data transaksi yang tersimpan pada system inventori

g. View Data Transaksi

Adapun activity diagram pada list praktikan dapat dilihat pada gambar 7 .

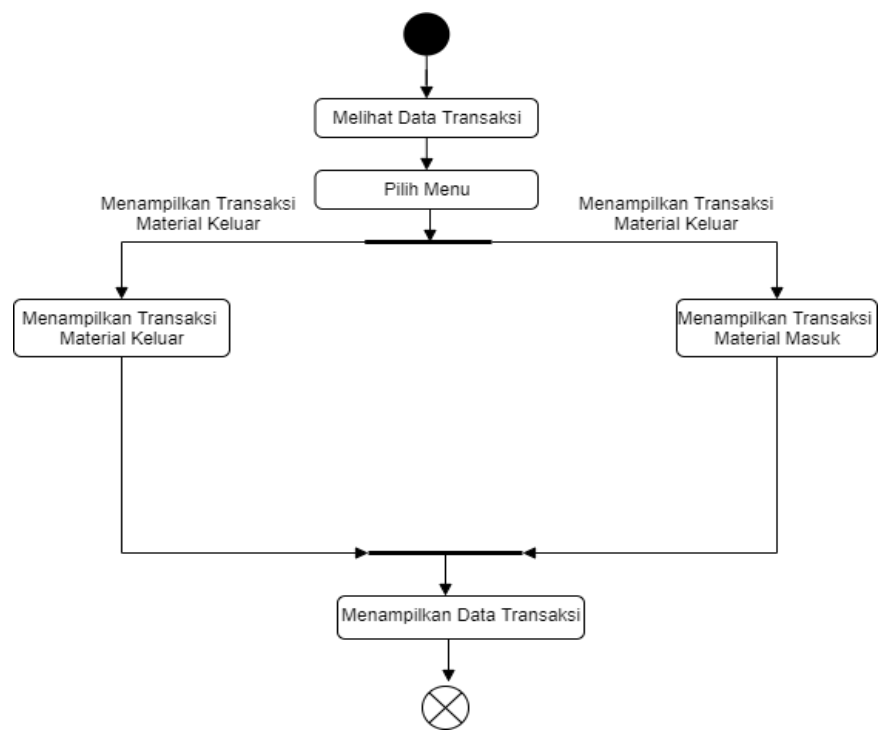

Gambar 7. view data transaksi 
h. Entry Data Material

Adapun activity diagram pada entry nilai dapat dilihat pada gambar 8

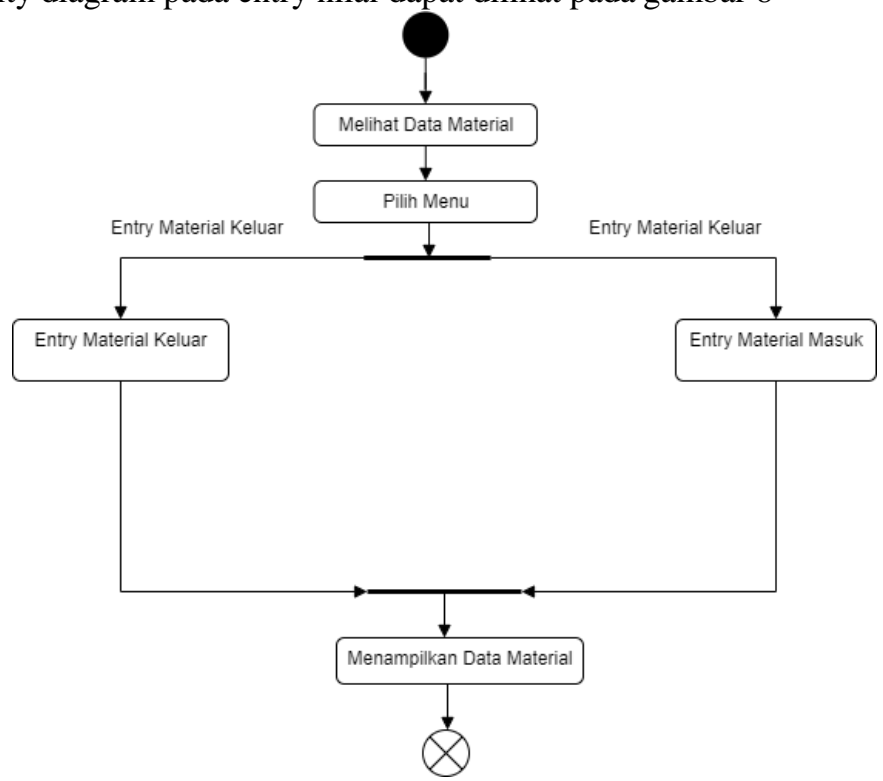

i. Cetak Laporan Transaksi

Gambar 8. Entry Data Material

Adapun activity diagram pada cetak laporan trsansaki dapat dilihat pada gambar 9

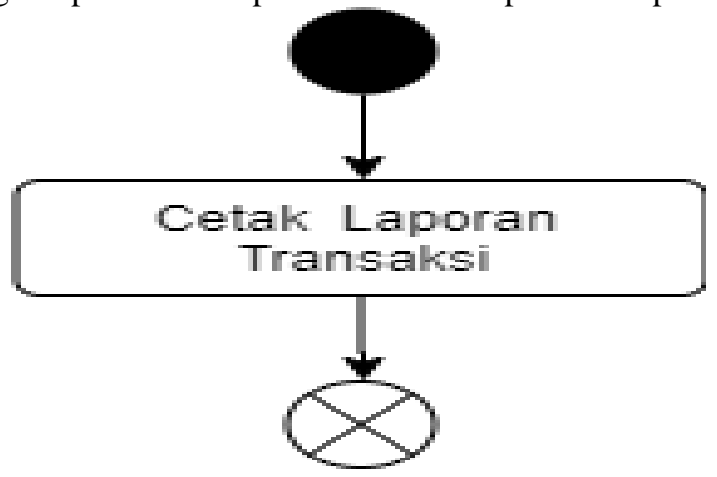

Gambar 9. Cetak Laporan Transaksi

Model Conceptual Data Model (CDM) membahas desain yang sah dari seluruh aplikasi informasi, bukan bergantung pada pemrograman atau perenungan model struktur informasi. CDM dapat diubah ke PDM CDM dalam aplikasinya dapat dibandingkan dengan ERD yang kapasitasnya pasti sangat mirip, alamat menunjukkan konstruksi cerdas dari basis informasi [16] Dari kebutuhan Fungsional tersebut dapat di gambarkan Desain Conceptual Data Model (CDM) pada gambar 10. Terdapat 8 tabel yang berelasi untuk penyimpanan data terstruktur. 


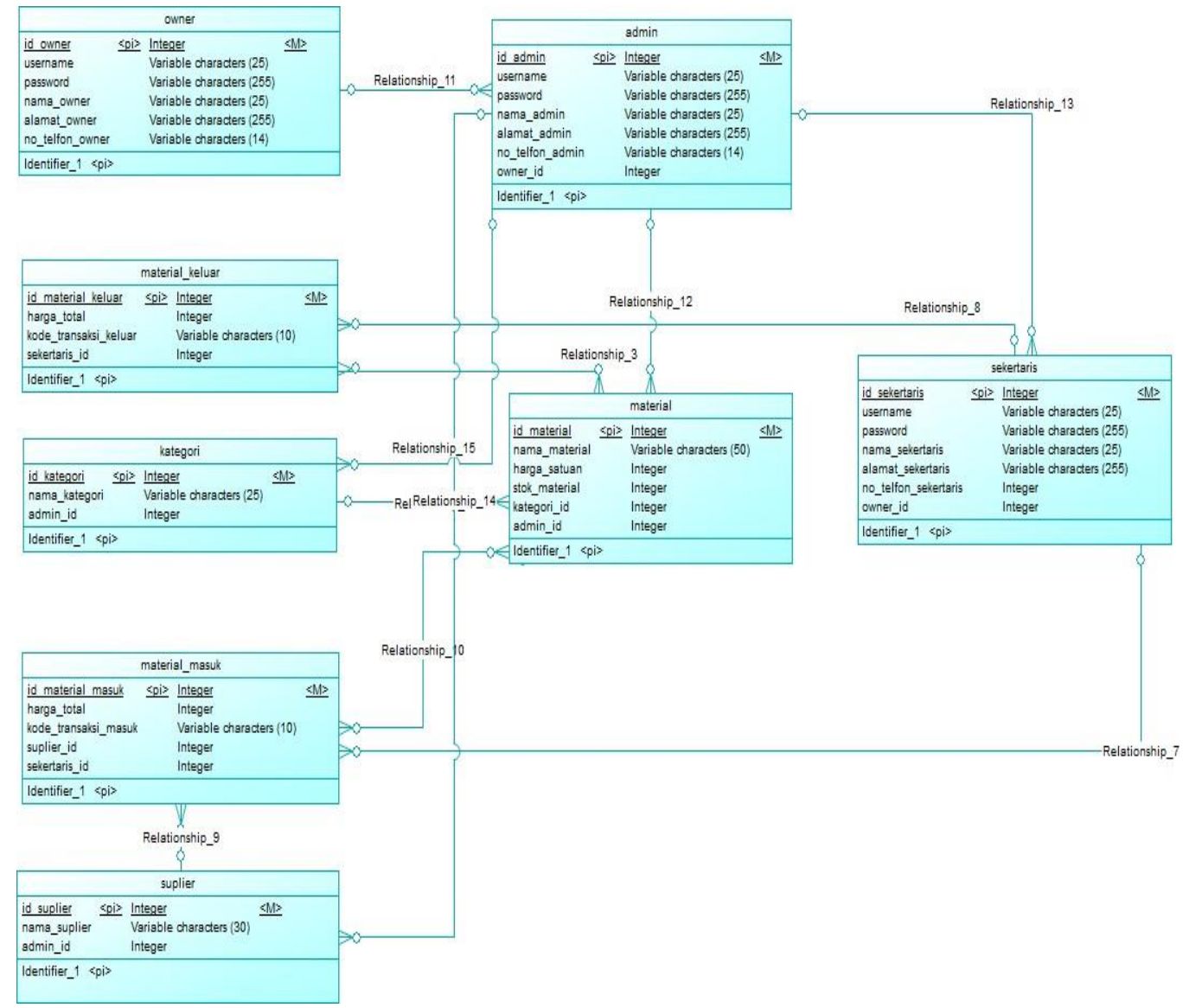

Gambar 10. Conceptual Data Model

\subsection{Hasil Analisis}

Dari analisis dan desain sistem yang telah dibuat, maka dibangunlah Sistem Informasi Inventori yang menghasilkan beberapa fitur. Pada gambar (11) dapat dilihat tampilan halaman dashboard Sementara untuk gambar (12) adalah tampilan halaman report transaksi keluar.

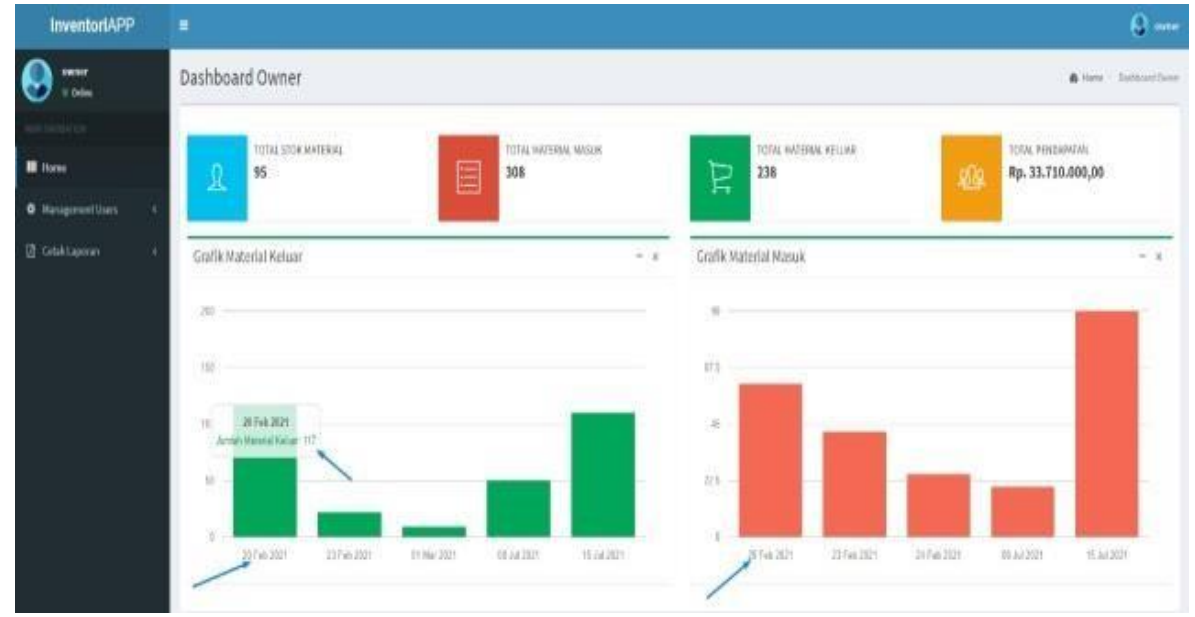

Gambar 11. Halaman Dashboard 


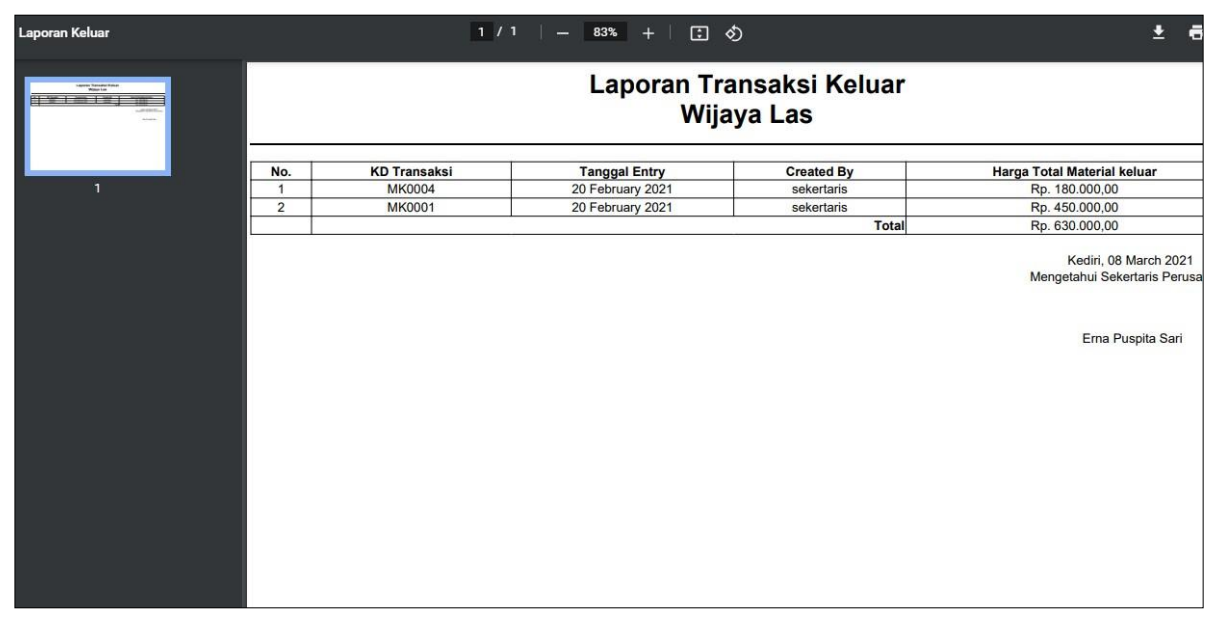

Gambar 12. Halaman Report Transaksi keluar

a. Tabel Black Box Testing

Uji aplikasi menggunakan black box testing fokus pada persyaratan fungsional dari perangkat lunak yang akan dibangun untuk menguji kelayakan aplikasi berikut adalah aktifitas pengujian aplikasi menggunakan black box testing dapat dilihat pada tabel berikut :

Tabel 1. Tabel Black Box Testing

\begin{tabular}{|l|l|l|l|}
\hline Aktivitas pengujian & $\begin{array}{l}\text { Realisasi yang } \\
\text { diharapkan }\end{array}$ & Hasil pengujian & Kesimpulan \\
\hline Masuk halaman awal & $\begin{array}{l}\text { Terhubung dengan } \\
\text { database }\end{array}$ & $\begin{array}{l}\text { menampilkan tampilan } \\
\text { halaman awal }\end{array}$ & $\begin{array}{l}(\checkmark) \text { Diterima } \\
(\text { ) Ditolak }\end{array}$ \\
\hline Klik tombol login & $\begin{array}{l}\text { Merujuk kehalaman } \\
\text { login }\end{array}$ & $\begin{array}{l}\text { Tombol login berfungsi } \\
\text { normal }\end{array}$ & $\begin{array}{l}\text { ( } \checkmark \text { ) Diterima } \\
\text { () Ditolak }\end{array}$ \\
\hline Masuk Halaman admin & $\begin{array}{l}\text { Terhubung dengan } \\
\text { database }\end{array}$ & $\begin{array}{l}\text { menampilkan halaman } \\
\text { admin }\end{array}$ & $\begin{array}{l}\text { ( } \checkmark \text { ) Diterima } \\
\text { () Ditolak }\end{array}$ \\
\hline $\begin{array}{l}\text { Masuk Halaman } \\
\text { sekretaris }\end{array}$ & $\begin{array}{l}\text { Terhubung dengan } \\
\text { database }\end{array}$ & $\begin{array}{l}\text { menampilkan halaman } \\
\text { sekretaris }\end{array}$ & $\begin{array}{l}\text { ( } \checkmark \text { ) Diterima } \\
\text { () Ditolak }\end{array}$ \\
\hline Masuk Halaman owner & $\begin{array}{l}\text { Terhubung dengan } \\
\text { database }\end{array}$ & $\begin{array}{l}\text { menampilkan halaman } \\
\text { owner }\end{array}$ & $\begin{array}{l}\text { ( } \checkmark \text { ) Diterima } \\
\text { () Ditolak }\end{array}$ \\
\hline $\begin{array}{l}\text { Masuk Halaman cetak } \\
\text { laporan pada halaman } \\
\text { owner }\end{array}$ & $\begin{array}{l}\text { Terhubung dengan } \\
\text { database }\end{array}$ & $\begin{array}{l}\text { menampilkan halaman } \\
\text { cetak laporan owner }\end{array}$ & $\begin{array}{l}(\checkmark) \text { Diterima } \\
\text { () Ditolak }\end{array}$ \\
\hline
\end{tabular}

Untuk menguji aplikasi dari sisi pengguna kami melakukan survey kepada staff owner sekretaris dan pemilik perusahaan menggunakan ISO 1926-3, ISO 9126 adalah salah satu standar internasional untuk mengevaluasi kualitas perangkat lunak [5]. 


\section{Uji Aplikasi pada sisi Pengguna dengan menggunakan ISO 9126-3}

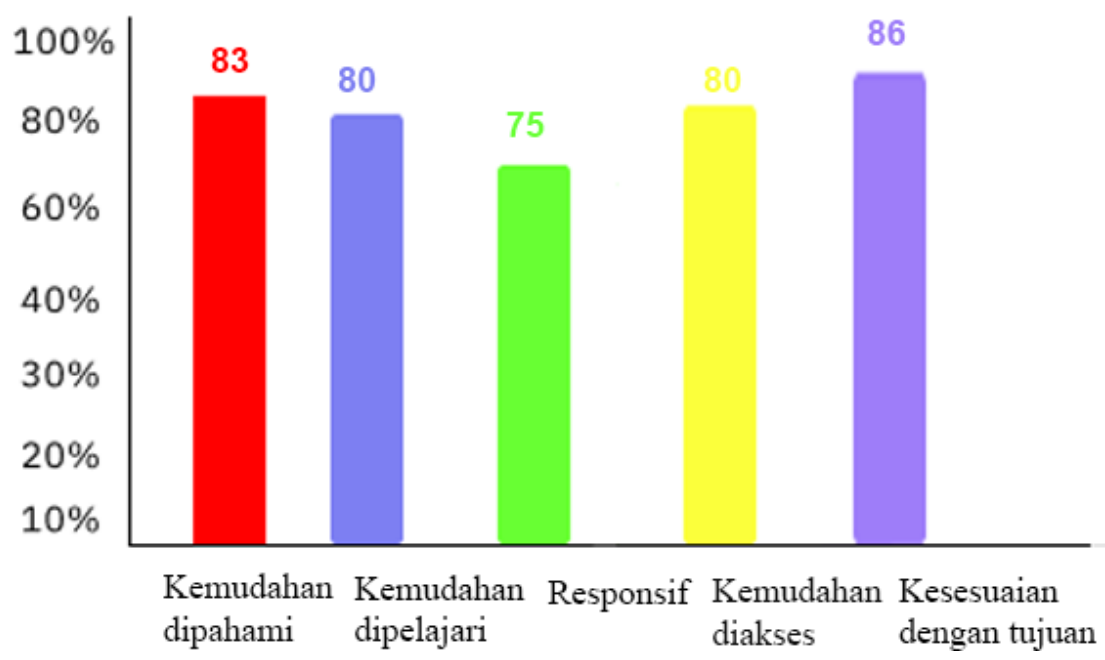

Gambar 13. Hasil Penilaian aplikasi system informasi inventory

\section{KESIMPULAN}

Pembuatan aplikasi system informasi inventori dilaksanakan dalam 4 bulan dengan menggunakan model waterfall aplikasi dapat digunakan oleh staff ataupun pemilik perusahaan. Pada penelitian ini kami melakukan uji kelayakan aplikasi dengan melakukan uji pada staff perusahaan CV Wijaya Las Untuk mengetahui layak atau tidaknya kami menggunakan ISO 9126-3 dan hasil dari penilaian diperoleh kemudahan dipahami sebesar $83 \%$, Kemudahan dipelajari sebesar $80 \%$ Responsif pada program sebesar $75 \%$ Kemudahan akses pada program sebesar $80 \%$ dan kesesuaian tujuan sebesar $86 \%$.

Dari kelima penilian aplikasi system informasi inventori yang dikembangkan peneliti memiliki nilai rata rata sebesar $80 \%$ yang berarti aplikasi system informasi inventori sangat layak digunakan untuk menyimpan data baik material material yang ada di CV Wijaya Las. Tujuan dalam pembuatan aplikasi aplikasi informasi inventori ini adalah untuk memudahkan staff dan pengelola perusahaan CV Wijaya Las dalam menyimpan data material masuk, maupun material keluar tanpa menggunakan kertas atau media manual dan memudahkan owner dalam melakukan pencetakan laporan transaksi.

\section{REFERENSI}

[1] E. Khikmawati, M. Anggraini, and K. Anwar, "Analisis Perencanaan Biaya Persediaan Produk Semen Melalui Pendekatan Perencanaan Kebutuhan Bahan Baku (Material Requirement Planning)," J. Rekayasa, Teknol. dan Sains, vol. 1, no. 1, 2017.

[2] M. Fadly, D. Suhendro, and A. Syahputra, "Perancangan Aplikasi Persediaan Barang dan Bahan Makanan Menggunakan Metode FIFO pada KFC Pematangsiantar,” J. Ilm. Media Sisfo, vol. 13, no. 1, p. 48, 2019, doi: 10.33998/mediasisfo.2019.13.1.527.

[3] F. Sonata, "Pemanfaatan UML (Unified Modeling Language) Dalam Perancangan Sistem Informasi ECommerce Jenis Customer-To-Customer," J. Komunika J. Komunikasi, Media dan Inform., vol. 8, no. 1, pp. 22$31,2019$.

[4] T. Hidayat and M. Muttaqin, "Pengujian sistem informasi pendaftaran dan pembayaran wisuda online menggunakan black box testing dengan metode equivalence partitioning dan boundary value analysis," 2020.

[5] A. Rachman, B. E. Prasetyo, R. Arief, and M. A. Ferdiansyah, "Pengembangan Aplikasi Game Pembelajaran Matematika ' Momon Math Run' Berbasis Desktop Menggunakan Model Waterfall," Semin. Nas. Sains dan Teknol. Terap. VII 2019, pp. 433-438, 2019.

[6] O. J. Okesola, A. A. Adebiyi, A. A. Owoade, O. Adeaga, O. Adeyemi, and I. Odun-Ayo, "Software 
Requirement in Iterative SDLC Model," in Computer Science On-line Conference, 2020, pp. 26-34.

[7] F. Frieyadie and T. Setiyorini, "IMPLEMENTATION OF INVENTORY INFORMATION SYSTEM DESIGN USING ECONOMIC ORDER QUANTITY METHOD,” J. Ris. Inform., vol. 3, no. 2, pp. 187-194, 2021.

[8] I. Ananda and E. Zuraidah, "Perancangan Sistem Informasi Penjualan Barang Pada PT Asia Truk Pratama Jakarta," J. Inform., vol. 6, no. 2, pp. 193-200, 2019.

[9] A. Zahir, "Pengembangan Media Pembelajaran Live Streaming Pengetahuan Komputer Berbasis Website," J. Ilm. d'COMPUTARE, vol. 9, no. 2, pp. 1-7, 2020.

[10] N. Tamsir and K. Alloto'dang, "Perancangan Aplikasi Manajemen Aset Sekolah Berbasis Web Service Pada Dinas Pendidikan Provinsi Sulawesi Selatan," in SISITI: Seminar Ilmiah Sistem Informasi dan Teknologi Informasi, 2019, vol. 8, no. 2.

[11] E. S. Soegoto, "Implementing Laravel framework website as brand image in higher-education institution," in IOP Conference Series: Materials Science and Engineering, 2018, vol. 407, no. 1, p. 12066.

[12] S. Butsianto and P. Riyanti, "Penerapan Sistem Pakar Menggunakan Metode Forward Chaining untuk Deteksi Penyakit pada Kucing Anggora Berbasis Web," J. SIGMA, vol. 9, no. 3, pp. 59-64, 2019.

[13] R. Agustin, T. Informatika, F. Teknik, and U. N. Surabaya, "PERANCANGAN SISTEM APLIKASI PENYEDIA JASA RENTAL MOBIL BERBASIS ( Studi Kasus : NUSA TRANS SURABAYA ) I Kadek Dwi Nuryana Abstrak," 2020.

[14] R. Lathif, “Apa Itu Draw.io ? Ini Penjelasan Lengkapnya,” 2019.

[15] M. Syarif and W. Nugraha, "Pemodelan Diagram UML Sistem Pembayaran Tunai Pada Transaksi ECommerce," J. Tek. Inform. Kaputama, vol. 4, no. 1, p. 70 halaman, 2020, [Online]. Available: http://jurnal.kaputama.ac.id/index.php/JTIK/article/view/240.

[16] S. Mukaromah, A. Pratama, S. A. Ithriah, and A. B. Putra, "Analysis and design student entrepreneurship information system,” J. Phys. Conf. Ser., vol. 1569, p. 22045, 2020, doi: 10.1088/1742-6596/1569/2/022045. 